\title{
CHEMOTAXIS AND CHEMICAL DEFENSES IN SEAWEED SUSCEPTIBILITY TO HERBIVORY
}

\author{
PEREIRA, R. C., ${ }^{1}$ DONATO, R., ${ }^{1}$ TEIXEIRA, V. L. ${ }^{1}$ and CAVALCANTI, D. N. ${ }^{2}$ \\ ${ }^{1}$ Departamento de Biologia Marinha, Instituto de Biologia, Universidade Federal Fluminense, C.P. 100.644, CEP \\ 24001-970, Niterói, Rio de Janeiro, Brazil \\ ${ }^{2}$ Programa de Pós-Graduação em Química Orgânica, Instituto de Química, Universidade Federal Fluminense, CEP \\ 24020-150, Niterói, Rio de Janeiro, Brazil \\ Correspondence to: Renato C. Pereira, Departamento de Biologia Marinha, Instituto de Biologia, \\ Universidade Federal Fluminense, C.P. 100.644, CEP 24001-970, Niterói, Rio de Janeiro, Brazil \\ Received March 26, 1999 - Accepted July 1, 1999 - Distributed August 31, 2000
}

(With 5 figures)

\begin{abstract}
Recent studies have show that small marine herbivores with limited mobility (mesograzers) often feed on macroalgae chemically defended against fishes or sea-urchins. In order to verify the involved mechanisms of chemotaxis or chemical defense into this process in Brazilian littoral, two species of brown alga Dictyota menstrualis and Dictyota mertensii were studied against the limited mobility herbivores, the amphipod Parhyale hawaiensis and the crab Pachygrapsus transversus. These two species were studied in order to verify the action of their crude extracts in the defense and chemotaxis processes related to limited mobility of these herbivores. Feeding preference assays revealed that $P$. hawaiensis do not eaten these Dictyota species. P. transversus do not eaten D. menstrualis either, but consumed large amounts of $D$. mertensii. Chemical deterrence assays showed that extracts of these species act as feeding deterrent to both species of herbivores. In addition, chemotaxis assays demonstrated that both herbivores are significantly negative chemotactic probably due to the presence of complementary metabolites into artificial foods. Considering that both Dictyota species exhibit active extracts against these small herbivores, we suppose that the non-occurrence of these herbivore species in close relationship with the seaweeds $D$. menstrualis and D. mertensii may explain the defense action of both extracts related to these mesograzers.
\end{abstract}

Key words: seaweed, chemical defense, chemotaxis, feeding.

\section{RESUMO}

\section{Quimiotaxia e defesas químicas na suscetibilidade de algas bentônicas frente à herbivoria}

Estudos recentes demonstram que defesas químicas de algas que inibem o consumo exercido por peixes ou ouriços não inibem herbívoros com pequena mobilidade. As espécies de algas bentônicas Dictyota menstrualis e Dictyota mertensii foram estudadas tendo por objetivo avaliar a atuação de seus extratos brutos nos processos de quimiotaxia e defesa frente aos herbívoros de pequena mobilidade, o anfípodo Parhyale hawaiensis e o caranguejo Pachygrapsus transversus. Os ensaios de preferência alimentar demonstraram que $P$. hawaiensis não consomem ambas as espécies de Dictyota. Por outro lado, $P$. transversus também não consomem $D$. menstrualis, mas se alimentam de grandes quantidades de $D$. mertensii. Os extratos brutos de ambas as espécies de Dictyota inbiram a herbívoria por estes herbívoros. Além disso, os ensaios demonstraram que os herbívoros apresentaram reação de quimiotaxia negativa, provavelmente devido à presença de metabólitos complementares presentes no alimento artificial. Considerando que ambas as espécies de Dictyota exibem extratos brutos ativos frente a estes herbívoros de pequena mobilidade, supomos que a não-ocorrência em estreita associação com as algas D. menstrualis e D. mertensii pode explicar os resultados obtidos.

Palavras-chave: alga bentônica, defesa química, quimiotaxia, herbivoria. 


\section{INTRODUCTION}

Secondary metabolites, also known as complementary metabolites (sensu Sammarco \& Coll, 1997) are considered more important and diverse than macromolecular toxins (Cavalier-Smith, 1992). In the marine environment, seaweeds, sponges, ascidian and soft corals produce a diverse array of complementary metabolites such as terpenoids, acetogenins, polyphenols (= phlorotannins) and alkaloids (Faulkner, 1997).

Complementary metabolites can mediate a wide range of ecological interactions between marine organisms, including seaweed chemical defenses against herbivores (Hay \& Steinberg, 1992; Paul, 1992), invertebrate chemical defense against predators (Pawlik et al., 1995; Sammarco \& Coll, 1988; Vervoort et al., 1998), anti-fouling or allelopathic relationships (Nys et al., 1991, 1995; Wahl, 1989), chemical mediation in reproduction of alcyonacean corals (Coll et al., 1989) and inhibition or induction to larvae metamorphose and recruitment (Pawlik, 1992).

Although several species of seaweeds belonging to Chlorophyceae, Phaeophyceae and Rhodophyceae exhibit complementary metabolites with broad ecological significance (Paul, 1992; Paul \& Alstyne, 1988), brown algae belonging to the order Dictyotales are well-known to produce the similar dictyols: dictyol B, dictyol B acetate, dictyol $\mathrm{E}$, dictyol $\mathrm{H}$ and pachydictyol $\mathrm{A}$, all that have been extensively tested as defenses against herbivores. In general, Dictyota produces complementary metabolites broadly defensive against a wide variety of consumers and fouling (Hay, 1992; Hay \& Steinberg, 1992; Schmitt et al., 1995). In spite of defensive characteristics of these brown algal compounds, some herbivores are tolerant to them and selectively consume plants that are chemically defended in relation to other herbivores (Hay, 1992). Defensive compounds against fishes and urchins do not affect small and relatively sedentary herbivores such as amphipods, polichaetes, and crabs. In fact, mesograzer herbivores subject to high potential predation rates may preferentially feed on this type of plants in order to minimize their susceptibility to natural enemies (Duffy \& Hay, 1994).

Despite the large literature about seaweed chemical defenses in Caribbean sea (e.g. Bolser \& Hay, 1996), in Guam - tropical Pacific (e.g. Pittik
$\&$ Paul, 1997) and North Carolina region (e.g. Cronin \& Hay, 1996a), little is known about abundance and ecological significance of seaweed complementary metabolites in South Atlantic region (e.g. Fleury et al., 1994; Pereira, 1998; Pereira et al., 1994; Pereira \& Yoneshigue, 1999). In the present work, we experimentally tested the presence of chemical mediation (chemotaxy and defense) between the Brazilian seaweeds $D$. menstrualis and D. mertensii related to two meso-herbivore species.

\section{MATERIAL AND METHODS}

\section{Study site and organisms assayed}

Seaweeds species Ulva fasciata, Dictyopteris delicatula, Dictyota menstrualis, Dictyota mertensii, Sargassum furcatum, Laurencia flagellifera, Rhodymenia pseudopalmata and Osmundaria obtusiloba (= Vidalia obtusiloba) were collected at Praia Rasa ("Shallow Beach"), located between Armação de Búzios and Cabo Frio, State

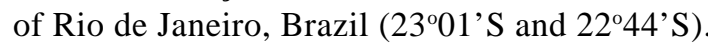
It possesses a rocky shore with a gentle slope about $20 \mathrm{~m}$ wide and it is considered to have the most diverse algal flora of the state (Pereira et al., 1994; Yoneshigue, 1985). Infralittoral fringe is characterized by dense cover of Sargassum spp., visible during the lowest tides and forming a continuous belt about $5 \mathrm{~m}$ wide along the shore where $S$. furcatum is one of the most abundant algal species (Yoneshigue, 1985).

It harbors a rich and varied associated fauna. Among gastropods, the most abundant is Tricolia afinis and other species such as Costoanachis sertularialum and Mitrella argus are also both rather dense. The dominant amphipod is Parhyale hawaiensis. Another conspicuous herbivore, the sea-urchin Echinometra lucunter, is usually found slightly above the $S$. furcatum belt. Specimens of P. hawaiensis for laboratory assays were also collected in this zone. However, individuals of the crab Pachygrapsus transversus were obtained closed to laboratory, at Praia de Boa Viagem, Niterói (Rio de Janeiro, Brazil).

\section{Feeding assays}

Before starting the experiments, both herbivore species were maintained feeding a diet of Ulva spp., because starvation can alter the exact feeding preference by some herbivorous, according to Cronin \& Hay (1996b). 
The seaweed susceptibilities to herbivory were verified through a choice experiment in which 8 previously weighted species of algae ( $U$. fas ciata, D. delicatula, D. menstrualis, D. mertensii, $S$. furcatum, $L$. flagellifera, $R$. pseudopalmata, and O. obtusiloba) were simultaneously presented to 10 specimens of $P$. hawaiensis $(\mathrm{n}=18)$. Control aquarium, without specimens of herbivores, containing one pre-weighed individual of each seaweed species and maintained under the same experimental conditions, allowed us to measure biomass variation due to autogenic factors and not by herbivory (Petterson \& Renaud, 1989). After 48 hours, algae were reweighted to evaluate the loss of biomass by herbivory. All weights were obtained from wet algae, from which the excess of water was blotted off using a "salad spinner". The consumed biomass was calculated using the equation $\left[\left(\mathrm{H}_{0} \times \mathrm{C}_{\mathrm{f}} / \mathrm{C}_{0}\right)-\mathrm{H}_{\mathrm{f}}\right]$, suggested by Cronin \& Hay (1996b). $\mathrm{H}_{0}$ and $\mathrm{H}_{\mathrm{f}}$ correspond to the initial and final wet masses, respectively, $\mathrm{C}_{\mathrm{o}}$ and $\mathrm{C}_{\mathrm{f}}$ to initial and final masses of the control.

Seaweed susceptibilities assays with the crab $P$. transversus used the same experimental design and procedures as in the amphipod ones. However, in the feeding preference tests 6 species of seaweeds were applied: $U$. fasciata, D. menstrualis, $D$. mertensii, $S$. furcatum, $L$. flagellifera, and $O$. obtusiloba $(\mathrm{n}=25)$.

\section{Mobility experiments}

Mobility or displacement of both herbivorous $P$. hawaiensis and P. transversus to each species of seaweed were assessed using a system in which pieces of seaweed were placed in equal distance of the herbivore in a small aquarium. For each replicate assay, 5 individuals of $P$. hawaiensis were placed in the center of the aquarium with seawater and the first contact with the seaweed species was observed. The assay was replicated 40 times. For the crab P. transversus the same methodology was applied but due to its behavior, two types of assays were done: in one of them seaweed species were offered in cages $(n=20)$, in the other there was no cage $(n=20)$.

\section{Extraction procedures}

The extracts of $D$. menstrualis and D. mertensii were prepared using a mixture of 2:1 dichloromethane and methanol. This combination of solvents tends to extract the lipophilic compounds better than these solvents alone (Cronin et al., 1995).

\section{Chemical deterrence assays}

Chemical deterrence of D. menstrualis and D. mertensii extracts was verified including natural concentrations of these extracts in an artificial food prepared according to Hay et al. (1994). Artificial foods (treatment and control - without extract) were included in a small square mesh (7 $\mathrm{x} 10$ squares) and offered simultaneously to herbivores. Both assays were run in small cups, each containing 7 individuals of $P$. hawaiensis (n $=13-18)$ and 1 individual of $P$. transversus $(\mathrm{n}=$ 16-17). The effect of extract on herbivory was determined comparing the number of square consumed in both experiment and control meshes.

\section{Chemotaxis - paired and multiple-choice assays}

Several assays were carried out to verify chemotaxy of extracts for both species $D$. menstrualis and D. mertensii to $P$. hawaiensis. Agar blocks were prepared using a similar procedure employed in the chemical deterrence assays but included in small acrylic molds $(2 \mathrm{~cm}$ diameter $\mathrm{x} 1 \mathrm{~cm}$ thickness). These are the assays that were developed: control blocks x blocks with $D$. menstrualis extract $(\mathrm{n}=20)$; control $\mathrm{x}$ blocks with $D$. mertensii extract $(\mathrm{n}=20)$; control $\mathrm{x}$ blocks with $D$. menstrualis extracts control x blocks with $D$. mertensii extract $(\mathrm{n}=20)$; control x $U$. fasciata blocks $(\mathrm{n}=15)$, and agar blocks $\mathrm{x}$ blocks with $D$. menstrualis extract $(\mathrm{n}=15)$. In all assays two or three options simultaneously to amphipods were offered. It was observed both the initial and final contacts of amphipod individuals with the artificial foods in each assay type.

\section{Statistical analysis}

Feeding preference or chemotaxis experiments with simultaneous offer of more than two alimentary items are very common in the ecological literature and the Analysis of Variance (ANOVA) or some variations of this are applied. However, this procedure becomes inadequate, because the samples (different species of seaweeds) are not independent (a low consumption of a single species could be interpreted as resultant of the high consumption of other). In most cases, there is no statistical analysis adapted to this type of experiment. It can take a confusion in the results 
if the animals consume, for example, great amounts of a type of low preference trying to compensate a low nutritional quality that is offered. Thus, the $t$ test was applied to the initial and final biomass of the algae, to verify the existence of difference of consumption for each species. On the other hand, to analyze the existence of alimentary preference between the species, the Friedman test was applied according to suggestion of Roa (1992), because this test doesn't demand independence between treatments. The remaining results of the experiments were analyzed by single $t$ test.

\section{RESULTS}

\section{Feeding assays}

The different susceptibilities of 8 algal species to herbivory by the amphipod $P$. hawaiensis are shown in Fig. 1.

The following decreasing sequence was observed among species (mg): U. fasciata (16.5) $>$ D. mertensii $(13.6)>S$. furcatum $(9.6)>L$. flagellifera $(3.3)>D$. menstrualis $(2.9)>D$. delicatula $(1.5)>R$. pseudopalmata $(-0.9)$ and $>$ O. obtusiloba $(-2.5)$.

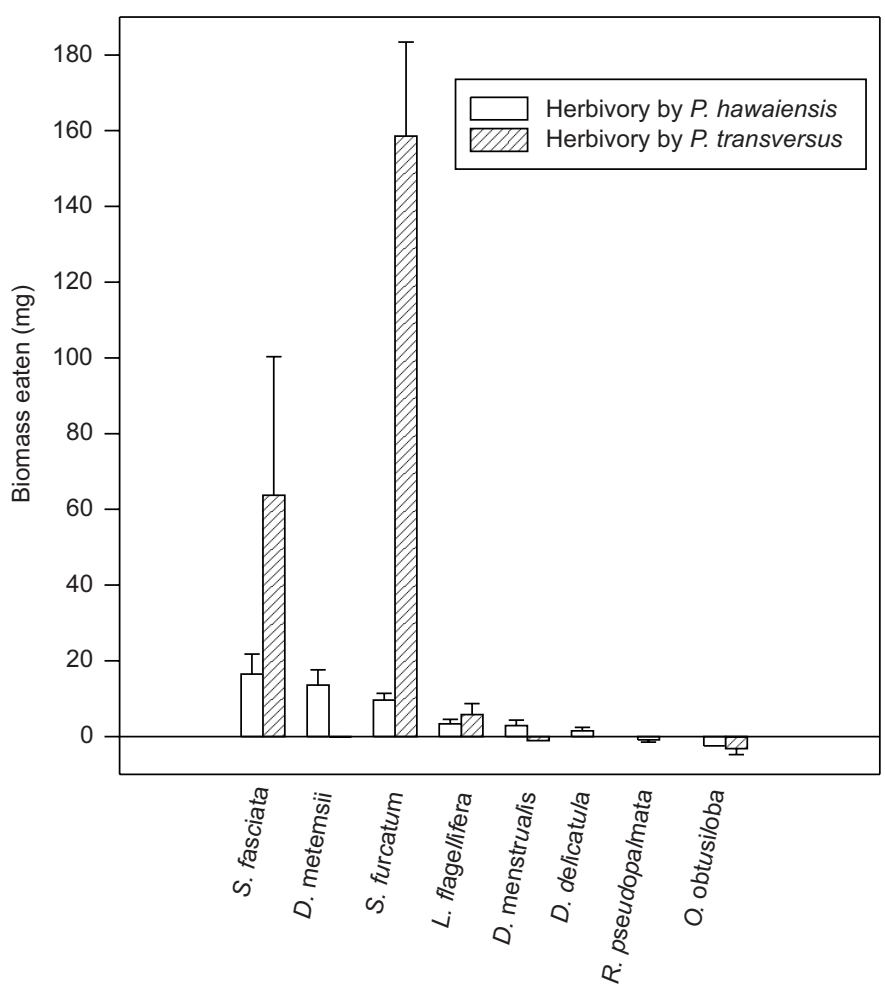

Fig. 1 - Differential susceptibility of seaweed species to herbivory by P. hawaiensis and P. transversus $(\mathrm{n}=10$ and $\mathrm{n}=$ 25 , respectively). Vertical bars in each point represent standard deviations.

Even without a concern with statistical treatment, it was observed that $U$. fasciata, D. mertensii and $S$. furcatum were more consumed when compared to the remaining species. In fact, these three species were all eaten at similar rates and initial and final biomass are different $(P<0.05)$. The Friedman test confirmed that $P$. hawaiensis eaten significantly more these three species $(P<$ $0.001)$.
For the crab $P$. transversus the following decreasing sequence $(\mathrm{mg}$ ) was observed (Fig. 1): S. furcatum (158.6) > U. fasciata $(63.7)>L$. flagellifera $(5.8)>D$. mertensii $(-0.1)>D$. menstrualis $(-1.1)>O$. obtusiloba $(-3.2)$. In fact, $P$. transversus significantly eaten more on $S$. furcatum and $U$. fasciata $(P<0.001$, Friedman test and $P<0.001, t$ test). It is interesting to note that the crab $P$. transversus also avoided the three 
species that were less eaten by the amphipod $P$. hawaiensis (L. flagellifera, D. menstrualis and $O$. obtusiloba). In contrast, of amphipod assay results, both species of Dictyota were avoided by $P$. transversus.

\section{Mobility experiments}

The results obtained from the taxis assays are plotted in Fig. 2. A major number of individuals of $P$. hawaiensis preferentially moved to $U$. fasciata (0.95 contacts), S. furcatum (0.92) and D. mertensii (0.87). A lower number of amphipods moved to L. flagellifera $(0.75)>O$. obtusiloba $(0.52)>D$. menstrualis (0.42). It is interesting to note that these results corroborated the susceptibility assay in which the species $U$. fasciata, D. mertensii and $S$. furcatum were more consumed by the amphipod P. hawaiensis (Fig. 1). The Friedman test demonstrated a significative difference between the most visited algae $(P<0.05)$.
What means that $P$. hawaiensis preferred to visit some species in detriment of others. In the taxis assays with cages (Fig. 3), more individuals of $P$. transversus moved to the species $O$. obtusiloba (6 contacts), L. flagellifera (5) and U. fasciata (3) than the other ones: S. furcatum (1), D. mertensii (1) and D. menstrualis. On the other hand, for assays without cages (Figure 3), they moved to $S$. furcatum (6) > O. obtusiloba $(4)>U$. fasciata $(3)>D$. mertensii (2) $>$ L. flagellifera $(1)>D$. menstrualis (zero). Both assays (caged or not caged) demonstrated that the crab avoided visiting both Dictyota species.

\section{Chemical deterrence assays}

In the assays carried out to verify the effects of the crude extracts of $D$. menstrualis and $D$. mertensii (Fig. 4) on feeding by P. hawaiensis it was observed that, in both assays, controls and experiments were consumed in different quantities $(P<0.05$, Wilcoxon test $)$.

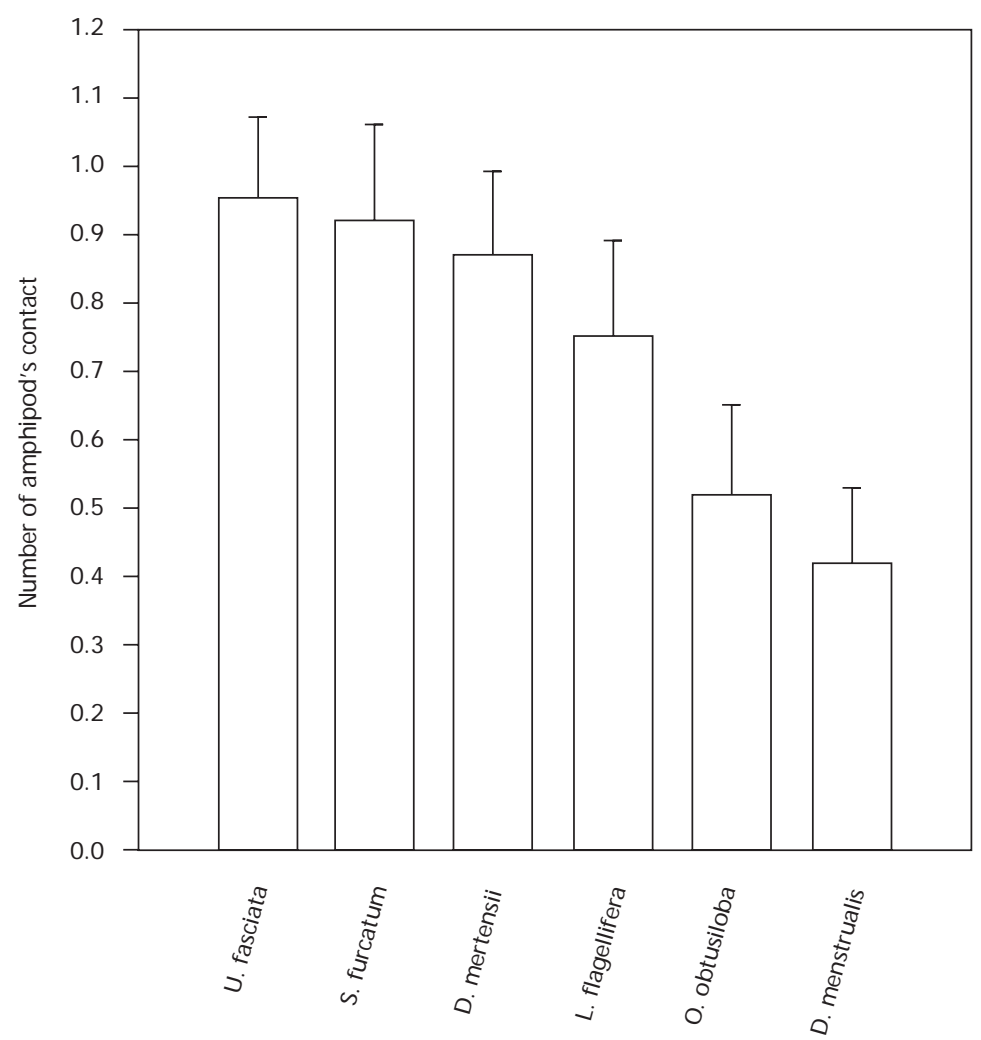

Fig. 2 - Taxis of P. hawaiensis to six seaweed species $(\mathrm{n}=40)$. Vertical bars in each point represent standard deviations. 


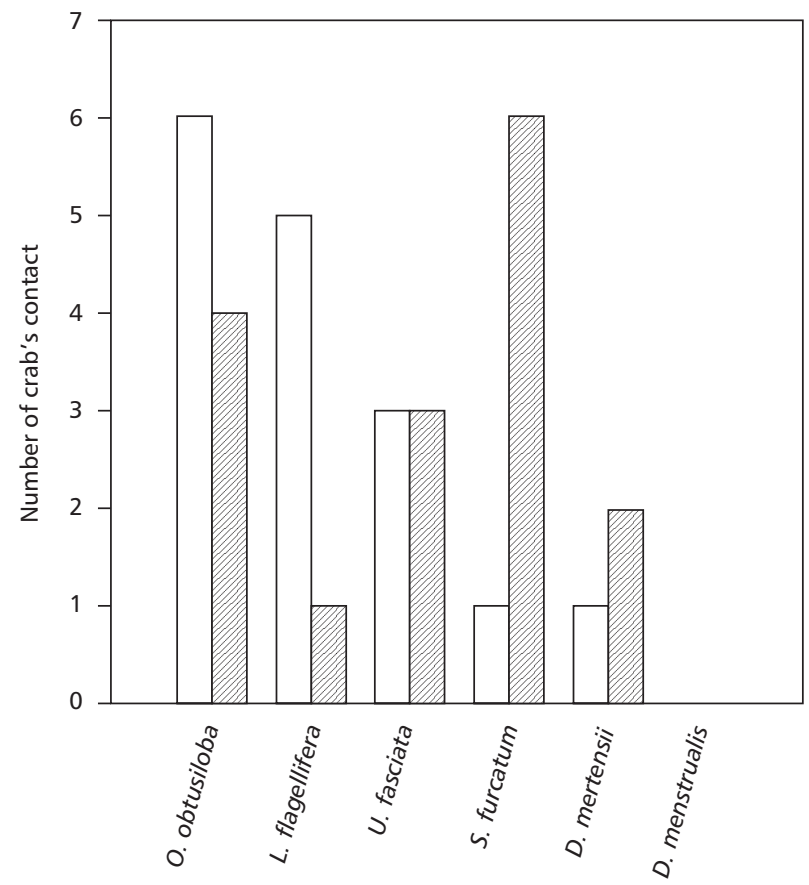

Fig. 3 - Taxis of P. transversus to six seaweed species in assay with cage $(\mathrm{n}=20)$ and without cage $(\mathrm{n}=20)$.

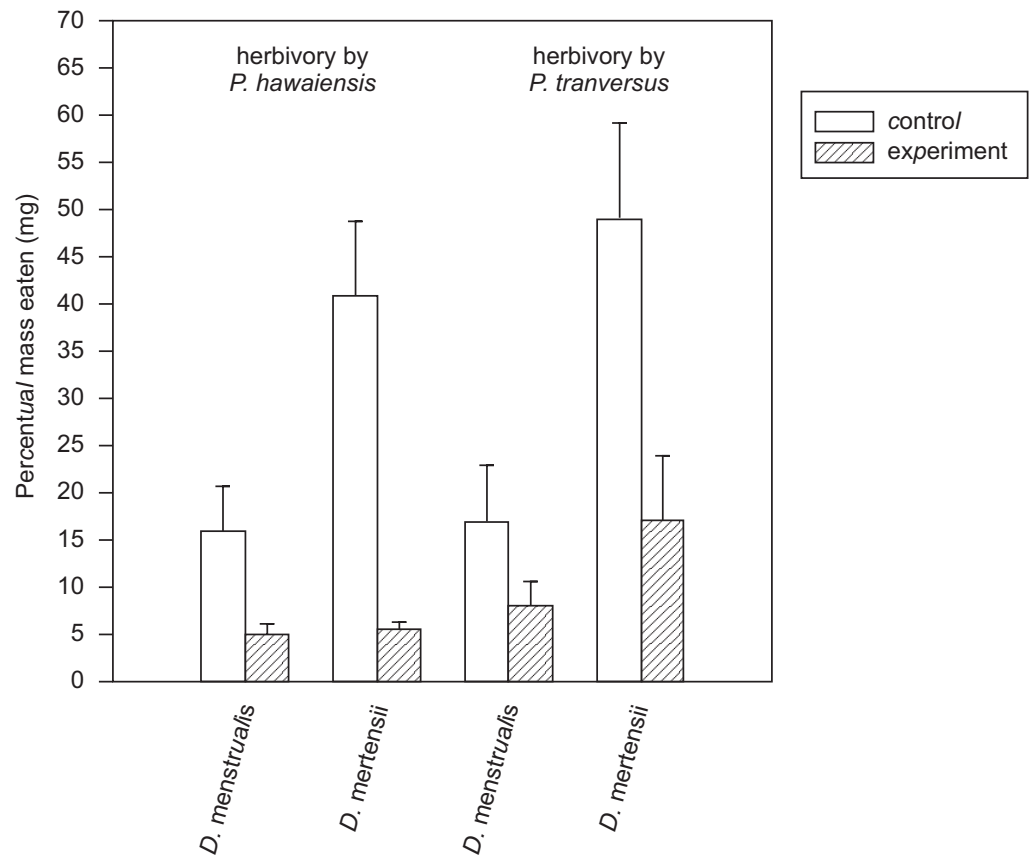

Fig. 4 - Effect of extracts from D. menstrualis and D. mertensii on herbivory by $P$. hawaiensis $(\mathrm{n}=13$ and $\mathrm{n}=18$, respectively) and $P$. transversus $(\mathrm{n}=16$ and $\mathrm{n}=17$, respectively). Vertical bars in each point represent standard deviations. 
Thus extracts of $D$. menstrualis and $D$. mertensii inhibited the herbivory by $P$. hawaiensis.

For $P$. transversus (Fig. 4), only D. mertensii extract inhibited the herbivory by this crab species $(P<0.01$, Wilcoxon test $)$. On the other hand, $D$. menstrualis extract did not inhibited $(P=0.29)$ the herbivory by this crab (Fig. 4).

\section{Chemotaxis assays}

In a choice experiment (Fig. 5), more individuals of $P$. hawaiensis moved to control blocks compared to other containing $D$. mertensii extract $(P<0.001$, Wilcoxon test). In the same way, individuals of $P$. hawaiensis avoided $(P<0.001$, Wilcoxon test $)$ contact with blocks containing D. menstrualis extract (Fig. 5).

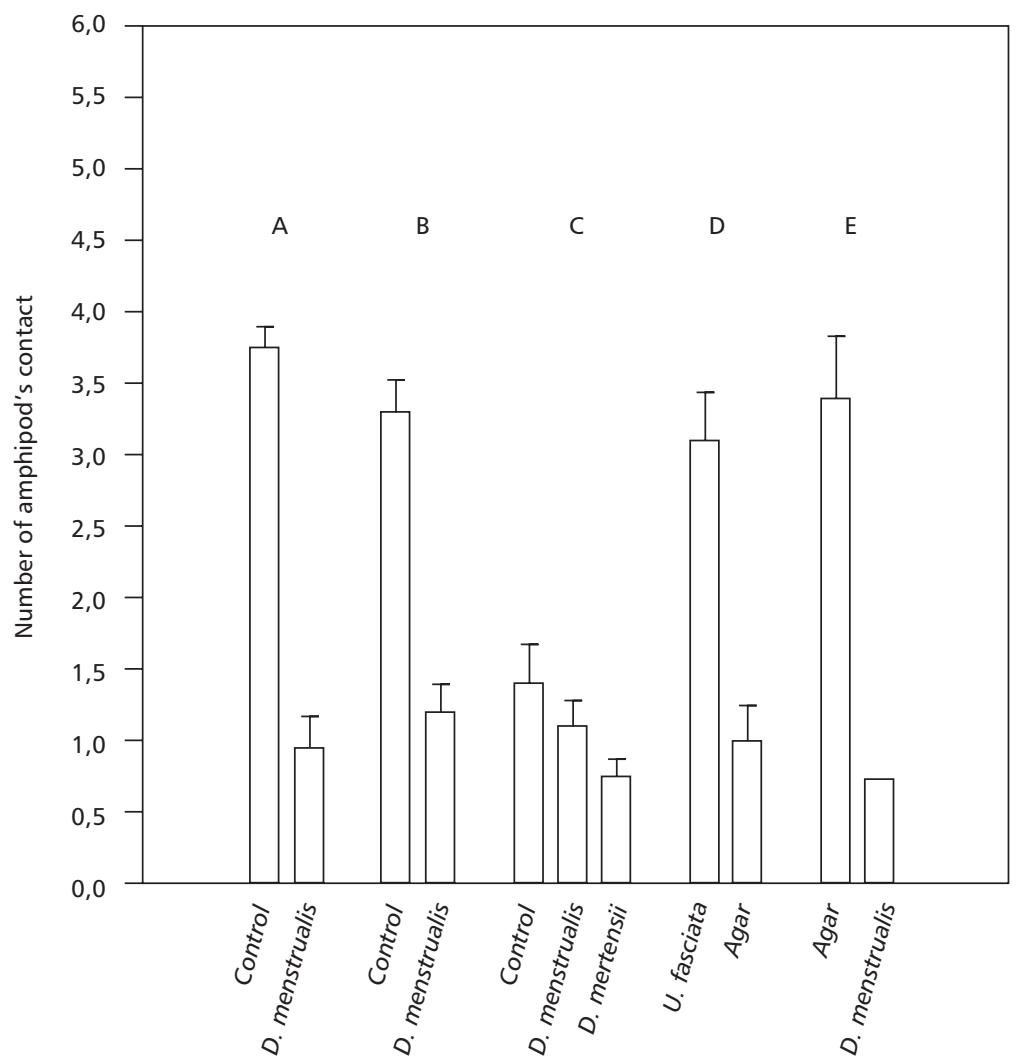

Fig. 5 - Chemotaxis of P. hawaiensis to D. menstrualis $(\mathrm{n}=40)$ and D. mertensii $(\mathrm{n}=40)$ extracts. A and B - assays carried out separately; C - extracts offered simultaneously $(\mathrm{n}=40)$; $\mathrm{D}$ - blocks containing only powder of $U$. fasciata and agar offered simultaneously $(\mathrm{n}=15)$; E - agar and D. menstrualis $(\mathrm{n}=15)$ extracts offered simultaneously. Vertical bars in each point represent standard deviations.

The same behavior was observed when three options were simultaneously offered, control blocks, blocks with extract of $D$. menstrualis and blocks containing extract of D. mertensii. More individuals of $P$. hawaiensis moved to control blocks compared to remaining blocks (Fig. 5).

Complementary assays in which blocks containing powder of $U$. fasciata and only agar blocks were simultaneously offered (Fig. 5), more individuals of $P$. hawaiensis moved to Ulva blocks
$(P<0.01$, Wilcoxon test). On the other hand, when agar blocks and $U$. fasciata blocks containing extract of D. menstrualis were offered (Fig. 5), the agar blocks were more visited $(P<0.01$, Wilcoxon test).

\section{DISCUSSION}

Several studies reveal important and meaningful aspects related to feeding preference of marine herbivores to alimentary sources, 
including the activity of complementary metabolites (Paul, 1992), nutritional values (Pennings et al., 1993), structure and toughness of the frond (Steneck, 1997) and susceptibility of the herbivore to predation (Duffy \& Hay, 1994). In fact, feeding preference experiments have been used in many contexts (Roa, 1992) and it can be considered primordial stages in experimental designs, mainly related to seaweeds.

The results of this study, demonstrated by feeding preference experiments, assume that the amphipod $P$. hawaiensis and the crab $P$. transversus consumed low amounts of $D$. menstrualis, whereas $D$. mertensii was not consumed by $P$. transversus but was preferred by $P$. hawaiensis. The extract of $D$. menstrualis in feeding assays was active against these herbivores and it is possibly responsible by low consumption verified in the feeding preference experiments. In fact, D. menstrualis is well-known to produce the diterpene pachydictyol A, a potent chemical defense against herbivory by Caribbean reef fish (Hay et al., 1987a), the fishes Diplodus holbooki (Hay et al., 1987b), Lagodon rhomboides (Hay et al., 1988a) and Siganus doliatus (Hay et al., 1988b), the amphipods Gammarus mucronatus (cited in Hay \& Steinberg, 1992), Hyale macrodactyla (Hay \& Steinberg, 1992) and the sea-urchin Diadema antillarum (Hay et al., 1987a).

We observed that the inhibition to herbivory by $P$. hawaiensis and $P$. transversus is probably due to other compounds than pachydictyol A. TLC analyzes demonstrated that the major compound belonging to other structural class exhibiting two aldehyde protons (see Appendix). Besides, preliminary assays showed that fraction containing this compound is active against these same herbivores, while the fraction with pachydictyol A was inactive (Pereira et al., 2000). In fact, pachydictyol A is effective as chemical defense against $P$. hawaiensis when in higher concentration (Pereira et al., 1994) more than found in D. menstrualis from Praia Rasa, Brazil.

Feeding assays also demonstrated that both extracts of $D$. menstrualis and $D$. mertensii were active against both $P$. hawaiensis and $P$. transversus. These results are according to feeding preference experiments with $P$. transversus, but not expected to $P$. hawaiensis that preferred $D$. mertensii in feeding ones (Fig. 1). D. mertensii is known to produce the diterpene dictyol $\mathrm{H}$ as major active compound, a defense against herbivores such as amphipods and fish (Hay et al., 1988a; Hay \& Steinberg, 1992). Our TLC showed that these species produce diverse complementary metabolites, but with distinct characteristics from dictyol $\mathrm{H}$. It is possible that this brown alga produce other major metabolites rather than dictyol $\mathrm{H}$ (see Appendix). Besides, this diterpene in natural concentration found in D. mertensii from Praia Rasa, did not inhibit herbivory by $P$. hawaiensis (Fleury et al., 1994).

The results from taxis assays revealed that $P$. hawaiensis preferred D. mertensii in detriment of D. menstrualis, a similar result observed in feeding preference experiments and extract assays. Our palatability results clearly evidenced the effective action of extract of D. menstrualis as chemical defense and negative attractiveness (chemotaxis) to $P$. hawaiensis. Chemotaxis was a direct measurement of the palatability of $D$. menstrualis to herbivory by $P$. hawaiensis. On the other hand, $P$. transversus in assays with and without cage shows low contact with both algal species $D$. menstrualis and $D$. mertensii. However, how explain feeding preferences of $P$. hawaiensis by $D$. mertensii fronds and its crude extract inhibition to this amphipod species? High nutritional values, not analyzed here, could probably explain this result. In general, chemical defenses are less effective in high than in low-quality foods (Duffy \& Paul, 1992). For example, the diterpene pachydictyol $\mathrm{A}$, as found in $D$. mertensii, only reduces fish feeding in lowquality food, but not in the high-quality one (Duffy \& Paul, 1992). Complementary assays demonstrated the validity of use the green palatable alga $U$. fasciata as attractive into artificial food. Besides, both assays revealed that in spite of its benthic habit (Tararam et al., 1978; Bousfield, 1973), P. hawaiensis was not moved by any substratum, but he seems to choose the substratum type. In this hypothesis, the block containing powder of $U$. fasciata would be less visited compared to blocks containing only agar, what did not happen. In the same way, when a block of $D$. menstrualis extract and an agar one were simultaneously offered, the majority of amphipods was observed on the agar blocks. Although the chemical basis on which amphipods discriminated between blocks with and without extract is unknown, they seem to "recognize" the presence of defensive metabolites found in untouched seaweeds or blocks containing extracts. For example, the amphipod Pseudamphithoides incur- 
varia moves to Dictyota species that exhibit defensive compounds or to Ulva coated with major compound found in this brown alga (Hay et al., 1990).

Finally, this study demonstrates defensive properties of $D$. menstrualis and $D$. mertensii extracts against the less mobility herbivores (= mesograzers) $P$. hawaiensis and $P$. transversus. The herbivores considered more specialized including some species of crab, amphipod and polichaete - avoid predation living and feeding on chemically defended seaweeds (Hay, 1992).

Rich-defensive seaweed to fish or sea-urchin herbivores may not act or stimuli mesograzer herbivores (Hay, 1992; Hay \& Steinberg, 1992). In fact these more specialized herbivores used to live associated with seaweeds to obtain food and protection against predation (Duffy \& Hay, 1994). In the natural environment, both $P$. hawaiensis and $P$. transversus are not living close to D. menstrualis or $D$. mertensii. This aspect can probably explain why complementary metabolites found in these brown algal species inhibit consume by these herbivores.

\section{APPENDIX}

The brown alga Dictyota is well known to produce a large and diverse number of complementary metabolites, mostly terpenoid compounds (Faulkner, 1997). Below, we present some observations about complementary metabolites found in Dictyota species analyzed by TLC (Thin Layer Chromatography).

D. menstrualis from Brazil - Our TLC of extracts showed numerous UV-active spots in the nonpolar region and RMN analysis revealed compounds exhibiting two aldehyde protons, probably belonging to compounds derived from xeniane carbon skeleton (Teixeira et al., 1999). Then, the major metabolites found in that extract seem to be other than the common pachydictyol A, found in this Dictyota species and responsible for defensive properties against herbivores (Hay \& Steinberg, 1992).

D. mertensii from Brazil - Crude extracts analyzed by TLC revealed a very diversified sterol compounds supposedly in high concentration, according to previous studies (Fleury et al., 1994). Preliminary assays and RMN analyzes suppose the presence of prenylated guaianes other than pachydictyol A or dictyol $\mathrm{H}$.
Acknowledgments - Financial support was provided by CNPq (PADCTII-QEQ, Proc. 62.0470/94.1) and FAPERJ (Proc. E26/170.881/96). R.C.P. and V.L.T. thank Brazilian Council for Research $(\mathrm{CNPq})$ for the Research Productivity Fellowships (Proc. 521914/96-5 and 303016/90-6, respectively). R.D. and D.N.C. thank CNPq and CAPES for Fellowships. Mark E. Hay provided the pachydictyol A standard to help us to interpret TLC plates of D. menstrualis and D. mertensii extracts. We also thank Edson P. da Silva and an anonymous reviewer for constructive comments on the manuscript.

\section{REFERENCES}

BOLSER, R. C. \& HAY, M. E., 1996, Are tropical plants better defended? palatability and defenses of temperate versus tropical seaweeds. Ecology, 77: 2269-2286.

BOUSFIELD, E. L., 1973, Shallow-water gammaridean amphipoda of New England. Cornell University Press. Canada.

CAVALIER-SMITH, T., 1992, Origins of secondary metabolism. Ciba Found. Symp., 171: 64-87.

COLL, J. C., BOWDEN, B. F., HEATON, A., SCHEUER, P. J., LI, M. K. W., ClARDY, J., SCHULTE, G. K. \& FINER-MOORE, J., 1989, Structures and possible functions of epoxipukalide and pukalide. Diterpenes associated with eggs of Sinularian soft corals (Cnidaria, Anthozoa, Octocorallia, Alcyonacea, Alcyoniidae). J. Chem. Ecol., 15: 1177-1191.

CRONIN, G. \& HAY, M. E., 1996a, Effects of light and nutrient availability on the growth, secondary chemistry, and resistance to herbivory of two brown seaweeds. Oikos, 77: 93-106.

CRONIN, G. \& HAY, M. E., 1996b, Susceptibility to herbivores depends on recent history of both the plant and animal. Ecology, 77: 1531-1543.

CRONIN, G., LINDQUIST, N., HAY, M. E. \& FENICAL, W., 1995, Effects of storage and extraction procedures on yields of lipophilic metabolites from the brown seaweeds Dictyota ciliolata and D. menstrualis. Mar. Ecol. Prog. Ser., 119: 265-273.

DUFFY, J. E. \& HAY, M. E., 1994, Herbivore resistance to seaweed chemical defense: the roles of mobility and predation risk. Ecology, 75: 1304-1319.

DUFFY, J. E. \& PAUL, V. J., 1992, Prey nutritional quality and the effectiveness of chemical defenses against tropical reef fishes. Oecologia, 90: 333-339.

FAULKNER, D. J., 1997, Marine natural products. Nat. Prod. Rep., 14: 259-301.

FLEURY, B. G., KELECOM, A., PEREIRA, R. C. \& TEIXEIRA, V. L., 1994, Polyphenols, terpenes and sterols in Brazilian Dictyotales and Fucales (Phaeophyta). Bot. Mar., 37: 457-462.

HAY, M. E., 1992, The role of seaweed chemical defenses in the evolution of feeding specialization and in the mediation of complex interactions, pp. 93-118. In: V. J. Paul (ed.), Ecological roles of marine natural products, Cornell University Press, Ithaca and London. 
HAY, M. E. \& STEINBERG, P. D., 1992, The chemical ecology of plant herbivore interactions in marine versus terrestrial communities, pp. 371-413. In: G. A. Rosenthal \& M. R. Berenbaum (eds.), Herbivores - their interactions with secondary plant metabolites, Academic Press, New York.

HAY, M. E., DUFFY, J. E. \& FENICAL, W., 1988a, Seaweed chemical defenses: among-compound and among-herbivore variance. Proc. 6th Int. Coral Reef Symp., 3: 43-48.

HAY, M. E., DUFFY, J. E. \& FENICAL, W., 1990, Host-plant specialization decreases predation on a marine amphipod: an herbivore in plant's clothing. Ecology, 71: 733743.

HAY, M. E., DUFFY, J. E., PFISTER, C. A. \& FENICAL, W., 1987a, Chemical defense against different marine herbivores: are amphipods insect equivalents? Ecology, 68: $1567-1580$

HAY, M. E., FENICAL, W. \& GUSTAFSON, K., 1987b, Chemical defense against diverse coral-reef herbivores. Ecology, 68: 1581-1591.

HAY, M. E., KAPPEL, E. Q. \& FENICAL, W., 1994, Synergisms in plant defenses against herbivores: interactions of chemistry, calcification and plant quality. Ecology, 75: 1714-1726.

HAY, M. E., RENAUD, P. E. \& FENICAL, W., 1988b, Large mobile versus small sedentary herbivores and their resistance to seaweed chemical defenses. Oecologia, 75 : 246-252.

de NYS, R., COLL, J. C. \& PRICE, I. R., 1991, Chemically mediated interactions between the red alga Plocamium brasiliense and the soft coral Sinularia cruciata. Mar. Biol., 108: 315-320.

de NYS, R., STEINBERG, P. D., WILLEMSEN, P., DWORJANYN, S. A., GABELISH, C. L. \& KING, R. J., 1995, Broad spectrum effects of secondary metabolites from the red alga Delisea pulchra in antifouling assays. Biofouling, 8: 259-271.

PAUL, V. J., 1992, Ecological roles of marine natural products. Cornell University Press, Ithaca and London, 245p.

PAUL, V. J. \& VAN ALSTYNE, K. L., 1988, The role of secondary metabolites in marine ecological interactions. Proc. $6^{\text {th }}$ Int. Coral Reef Symp., 1: 175-186.

PAWLIK, J. R., 1992, Chemical ecology of the settlement of benthic marine invertebrates. Oceanogr. Mar. Biol. Ann. Rev., 30: 273-335.

PAWLIK, J. R., CHANAS, B. TOONEM, R. J. \& FENICAL, W., 1995, Defenses of Caribbean sponges against predatory reef fish. I. Chemical deterrence. Mar. Ecol. Prog. Ser., 127: 183-194.

PEREIRA, R. C., 1998, Perspectivas da Ecologia Química no Brasil: as defesas químicas das algas bentônicas. Anais IV Congresso Latino-Americano; II Reunião IberoAmericana e VII Reunião Brasileira de Ficologia, pp. 103-111.
PEREIRA, R. C., CAVALCANTI, D. N. F. \& TEIXEIRA, V. L., 2000, Effects of secundary metabolites from the tropical Brazilian brown alga Dictyota menstrualis (Hoyt) Schemetter, Hörning \& Weber-Peukert on amphipod herbivorous. Mar. Ecol. Prog. Ser., in press.

PEREIRA, R. C., TEIXEIRA, V. L. \& KELECOM, A., 1994, Chemical defenses against herbivores in marine algae. 1. The brown alga Dictyota dichotoma (Hudson) Lamouroux from Brazil. An. Acad. Bras. Cienc., 66: 229-235.

PEREIRA, R. C. \& YONESHIGUE-VALENTIN, Y., 1999 , The role of polyphenols from the tropical brown alga Sargassum furcatum on the feeding by amphipod herbivores. Bot. Mar., 42: 441-448.

PENNINGS, S. C., NADEAU, M. T. \& PAUL, V. L., 1993 , Selectivity and growth of the generalist herbivore Dolabella auricularia feeding upon complementary resources. Ecology, 74: 879-890.

PETERSON, C. H. \& RENAUD, P. E., 1989, Analysis of feeding preference experiments. Oecologia, 80: 82-86.

PITTIK, T. J. \& PAUL, V. J., 1997, Effects of toughness, calcite level, and chemistry of crustose coralline algae (Rhodophyta, Corallinales) on grazing by the parrotfish Chlorurus sordidus. Proc. $8^{\text {th }}$ Int. Coral Reef Symp., 1: 701-706.

ROA, R., 1992, Design and analysis of multiple-choice feeding-preference experiments. Oecologia, 89: 509-515.

SAMMARCO, P. W. \& COLL, J. C., 1988, Chemical adaptations in the Octocorallia: evolutionary considerations. Mar. Ecol. Prog. Ser., 88: 93-104.

SAMMARCO, P. W. \& COLL, J. C., 1997, Secondary metabolites - or primary? Re-examination of a concept through a marine example. Proc. $8^{\text {th }}$ Int. Coral Reef Sym., 2: $1245-1250$.

SCHMITT, T. M., HAY, M. E. \& LINDQUIST, N., 1995, Constraints on chemically mediated coevolution: multiple functions of seaweed secondary metabolites. Ecology, 76: 107-123.

STENECK, R. S., 1997, Crustose corallines, other algal functional groups, herbivores and sediments: complex interactions along reef productivity gradients. Proc. 8th Int. Coral Reef Symp., 1: 695-700.

TARARAM, A. S., WAKABARA, Y. \& LEITE, F. P. P., 1978 Notes on Parhyale hawaiensis (Dana), Crustacea Amphipoda. Bull. Mar. Sci., 28: 783-786.

TEIXEIRA, V. L., CAVALCANTI, D. N. \& PEREIRA, R. C. 1999, Chemosystematic and biogeographic studies from the brown alga Dictyota menstrualis. Biochem. Syst. Ecol., in press.

VERVOORT, H. C., PAWLIK, J. R. \& FENICAL, W., 1998, Chemical defense of the Caribbean ascidian Didemnum conchyliatum. Mar. Ecol. Prog. Ser., 164: 221-228.

WAHL, M., 1989, Marine epibiosis. I. Fouling and antifouling: some basic aspects. Mar. Ecol. Prog. Ser., 58: 175-189.

YONESHIGUE, Y., 1985, Taxonomie et ecologie des algues marines dans la région de Cabo Frio (Rio de Janeiro, Brésil). Thèse Doct. Sci. Fac. Sci. Luminy. Univ. AixMarseille II. 466p. 